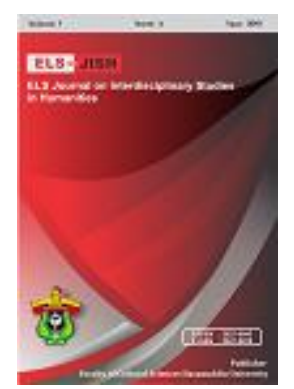

ELS-JISH

ELS Journal on Interdisciplinary Studies on Humanities

Volume 2 Issue 3, 2019

ISSN (print) : 2621-0843

ISSN (online) : 2621-0835

Homepage : http://journal.unhas.ac.id/index.php/jish

\title{
Exploring The Millennial Learners' Attributes and Needs in Educational Environment
}

\author{
Siti Hajar Larekeng ${ }^{1}$, Abdul Hakim Yassi ${ }^{2}$, Muhammad Najib ${ }^{3}$, Badaruddin ${ }^{4}$ \\ 1 sitihajar7773@gmail.com
}

\begin{abstract}
Millennial learners were born and raised in the digital era, with a variety of technology complete and sophisticated, such as: computer, laptop/notebook/netbook, smart Phone, iPads, PDA, MP3 player, internet, and various other electronic devices. From childhood, they were familiar or introduced with the sophisticated gadgets that directly or indirectly influence their behavioral development and personality. Millennial generation has characteristics of behavior and personality that is different from previous generation. The attributes of millennial learners who grown up with technology may influence the current teaching strategy. In supporting the urgency of exploring the millennial learners' attributes and needs in educational environment, the authors conduct a survey at Education Faculty of Universitas Muhammadiyah Parepare (UM Parepare), especially the learners who are majoring in English Education. The survey confirmed that those learners were exposed to various types of IT application. Some indications can be extracted from this study. Firstly, the learners were reasonably comfortable in utilizing various types of IT tools and expected the application to be embedded in the current application of learning. Secondly, the learners preferred to try to web in obtaining information, so the use of internet to access learning materials are highly needed. Last but not least, learners were mostly rated to adopt most ICT tools and devices.
\end{abstract}

Keywords: Millennial Learners, Needs and Attributes, Educational Environment

How to cite: Larekang, H. S., et al. (2019). Exploring The Millennial Learners' Attributes and Needs in Educational Environment. ELS Journal on Interdisciplinary Studies in Humanities, 2 (3), 389-397

\section{Introduction}

Today's millennial learners are the first generation who comes to the digital society. Computers, smart phones, and global communications have shaped and educated this generation. The knowledge practices of millennial learners are different from previous generations, even though there is no reason to assume that their cognitive system is profoundly different from ours. They have just extended their minds differently with various technology tools. It is crucial to enhance inventive pedagogies that concurrently support the acquirement of a deep knowledge base and understanding of 21 st century skills.

\footnotetext{
${ }^{1,4}$ Universitas Muhammadiyah Parepare, Indonesia

${ }^{2,3}$ Hasanuddin University, Indonesia
} 
The increase rate of so called "Internet generation" coming into higher education has been considered to pose new challenge to current higher education. This generation is popularly called as Digital Natives or millennial (Prensky, 2001); Generation Y (Mc Crindle, 2003); Net Generation (Oblinger \& Oblinger, 2005; Tapscott, 1999). They are assumed to familiar with most types of ICT tools while at the same time possess high level of involvement with social networking activities. Some of the familiar titles associated with this generation include "GenMe," "The Entitled Generation," "Generation-Y," "Gen Next," "Digital Generation," and "Echo Boom Generation." Higher education policy makers need to consider the terms of the new generation of learners.

The guidance of how to implement the 21st century skills is covered in document of Badan Standarisasi Nasional Pendidikan (BSNP, 2010). It contains the roles of teachers and learners in the 21st century education. In the 21stcentury, education is becoming increasingly important to ensure learners should have the skills to learn and innovate, skills in using information technology and media, as well as be able to work and survive by using life skills. Teachers should realize that there is a paradigm shift that is believed to be done by all stakeholders in order to improve the quality and relevance of education to enter the millennial world. Another key point, new learning approach that fits the needs of the 21st century learners should be implemented simultaneously.

Today's learners are more personalized in their own learning environment (Nussbaum-Beach \& Hall, 2012, p.11). They need to discover meaningful ways of using technology for learning purposes and collaborative knowledge creation. Therefore, there is a need to investigate the millennial learners need and attributes educational environment.

\section{Understanding of Millennial Learners' Attributes and Needs}

Millennial learners were born and raised in the digital era, with a variety of technology complete and sophisticated, such as: computer/laptop/notebook/netbook, smartphone, iPads, and various other electronic devices. From childhood, they are familiar or introduced with the sophisticated gadgets that directly or indirectly influence the behavioral development and personality. According to Tapscott (1997), this millennial learners tend to be a good collaborator and prefer to use intercative learning. Furthermore, Prensky (2001) argues that within the era of digital technologies, and considering the skills that owned by the millennial learners, all teachers have to adopt new methods to facilitate the learning process. Moreover, he claims that technology has changed the brains of Digital Natives.

The millennials own their capability in operating technology tools (Howe \& Strauss, 2006). They continue their higher education with unique experiences more diverse than any previous generation of college learners. The challenge for college faculty becomes one of understanding this new breed of learners and creating a range of teaching techniques that is responsive to their needs and styles. Rather than being told things they might rather construct their own learning from a range of sources (Oblinger and Oblinger 2005). Establishing a relationship is important for this generation. The more relaxed the environment; the more socially conducive to discussions, the better will be the quality of their learning (McCrindle 2003). Millennial generation has characteristics of behavior and personality that are different from 
previous generations. The attributes of millennial learners who have grown up with technology that may influence the way we teach. Previous studies identified various attributes of millennial learners. First, they are the "digital generation" who are proficient and passionate about information technology and various computer applications. They can access the various information they need easily and quickly, both for the benefit of education and the interests of daily life (Starlink, 2004). Millennials obviously get used to quicker to computer and net services as a result of they need invariably had them (Sweeney, 2006).

Second, the millennial learners are called as social human being, that they are very intense communication and interact with all circles, especially with peers through various networking sites, such as: Facebook, Instagram, WhatsApp, Line, or Path. Through this application, they can express what they perceive and think spontaneously. They also ignore the cultural background differences in their learning environment (Sudrajat,2012; Regina and Mc.Grath,2015).

Another crucial attribute is nomadic communication style. In this case, millennials have more friends and communicate with them more frequently using IM (instant messaging), text messaging, cell phones as well as more traditional communication channels. They are prolific communicators. They prefer to mobile communication. (Sweeney, 2006). Using the analysis of the millennials' attributes and their expectations for education, Beard,et.al (2007) describes enhancements that can be made to current teaching environments based upon the characteristics of the millennial learner. Firstly, technology-enhanced learning in which learners prefer hands-on learning rather than lectured material. With their interest in and adeptness to technology, increased integration of technology into the classroom is essential. Secondly, group projects and interaction which indicate that learners prefer to work in groups and solve problems in teams rather than individually. Learners also prefer experiential learning projects that contribute to society rather than constructed exercises to fulfill a requirement. Last, flexible learning environments means with the incorporation of group projects and technology-oriented learning, accommodations may need to be made on campuses to enable learners to work in groups and access technical resources. To address the needs of a more active learning environment, institutions need to be willing to modify their learning areas to enable this style of learning.

In supporting the urgency of exploring the millennial learners' attributes and needs in educational environment, the authors conduct a survey at Education Faculty of Universitas Muhammadiyah Parepare, especially the learners who are majoring in English Education.

\section{Method}

This study applied survey research design which then used the questionnaire in collecting data. The questionnaire aimed to dig in more deeply information on how the learners' access on technology, their web activities, their preference in finding information, their expectation on using IT in education, and their self-description on using ICT. This study took place in Universitas MuhammadiyahParepare (UM Parepare) especially the learners of English Education Program . The researcher was eager to know what the learners' expectation to the use of Web 2.0 in higher education . Primary data sources are millennial learners who are familiar and open- 
minded toward technologies. Total of population was 55. Based on Isaac-Michael Nomogram (Sugiyono, 2016) with sampling error 5\%, then researcher will take 48 learners as participant/sample. Sampling error $5 \%$ is intended to reduce the probability of generalization error.

The data obtained from questionnaire will be analyzed quantitatively by conducting statistical calculation on data collected. The quantitative data sources involved in this research is derived from the questionnaire distributed to learners. Then, all of these will be analyzed to make sense of the texts and to develop answers to the main research question.

\section{Results}

\subsection{The learners' access on technology}

This questionnaire is adapted from Khalid (2010) who investigates and describes the educational importance of Web 2.0 especially Podcasts, Wikis, and Blogs as possible sources to facilitate class room learning in higher education in Sweden. In this regard, the researcher adds some ICT tools that are possibly accessed by learners such as smartphone and internet access. The survey confirmed that almost all learners had high access to computers, smart phone and internet. High access to these tools indicates high mobility and a quick access to internet facilities. Please look at chart 1.

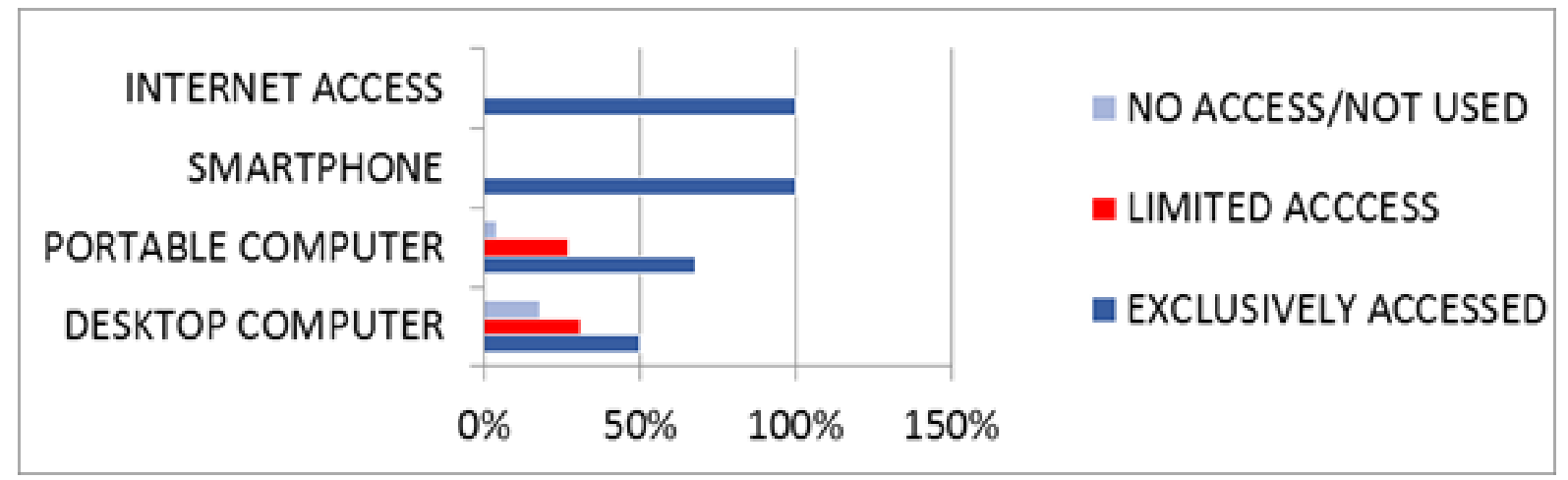

Figure 1.The learners' access on technology

\subsection{Learners' Web activities}

This questionnaire is also adapted from Khalid (2010). The survey shown that learners were reasonably comfortable in utilizing various types of IT tools. The use of internet to access learning materials was highly needed by learners (77\%). More, the learners showed often sending and receiving email (56\%). The study also found several activities that may lead towards the use of web for informal learning activities such as watching videos (64\%)and socializing (68\%). This condition can be seen in chart 2. 


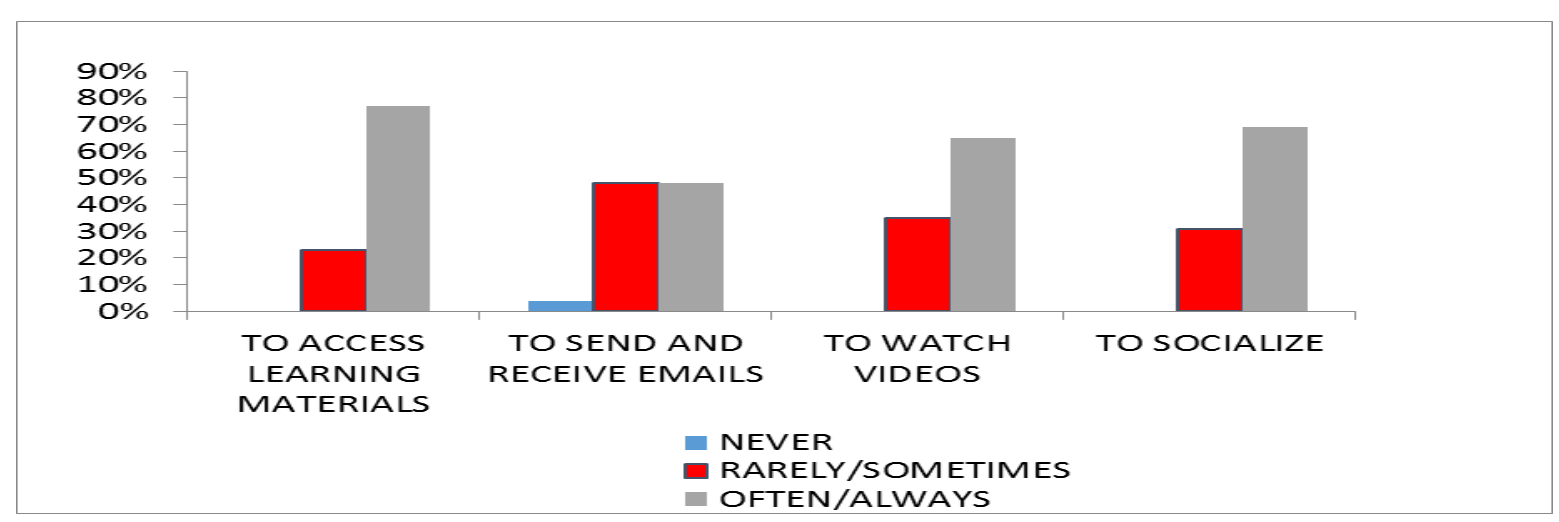

Figure 2. Learners' Web activities

\subsection{Learning Preference}

These following questionnaires (about learning preference, learning expectation and learners' attitude) were adapted from Aucoin (2014) who explored the views of adult learners in online university programs with respect to their relationships with interactive, web-based technologies in their learning, personal and work environments.

The survey confirmed that most of learners preferred to use search engines $(58 \%)$ in finding information than to ask friends $(25 \%)$ or teachers (17\%). Undoubtedly, it indicated that the role of internet was highly needed. Please look at figure 3.

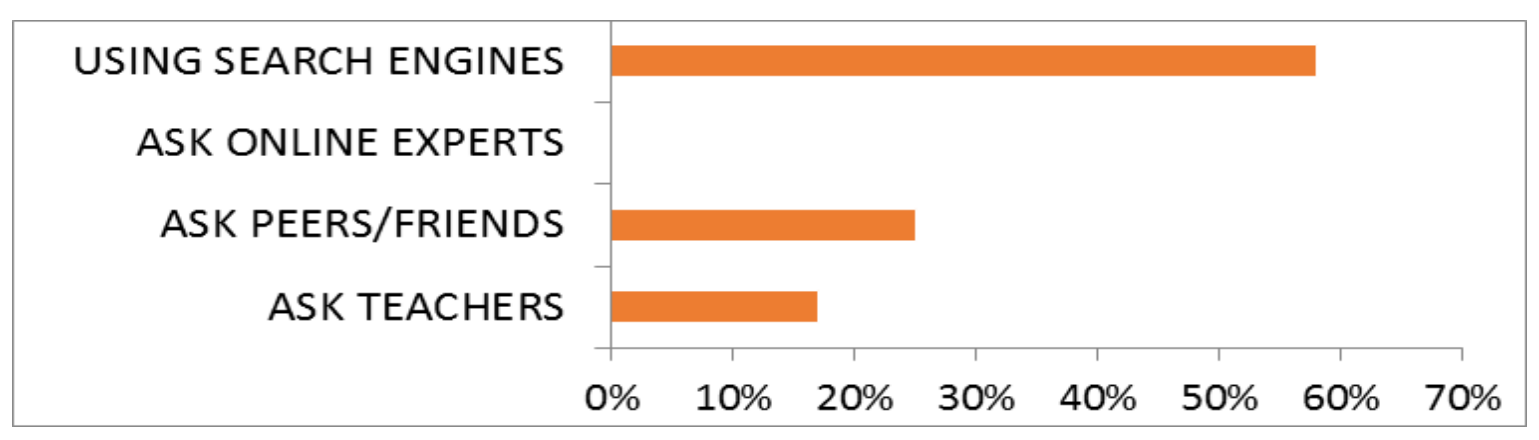

Figure 3. Learning Preference

\subsection{Learners' Expectation}

Furthermore, the survey assured that most of learners (58\%) expected using IT in classroom moderately. Even, a part of them expected a lot of using of IT (35\%) in classroom. It indicates that the existence of IT is undeniably demanded. Please look at figure 4.

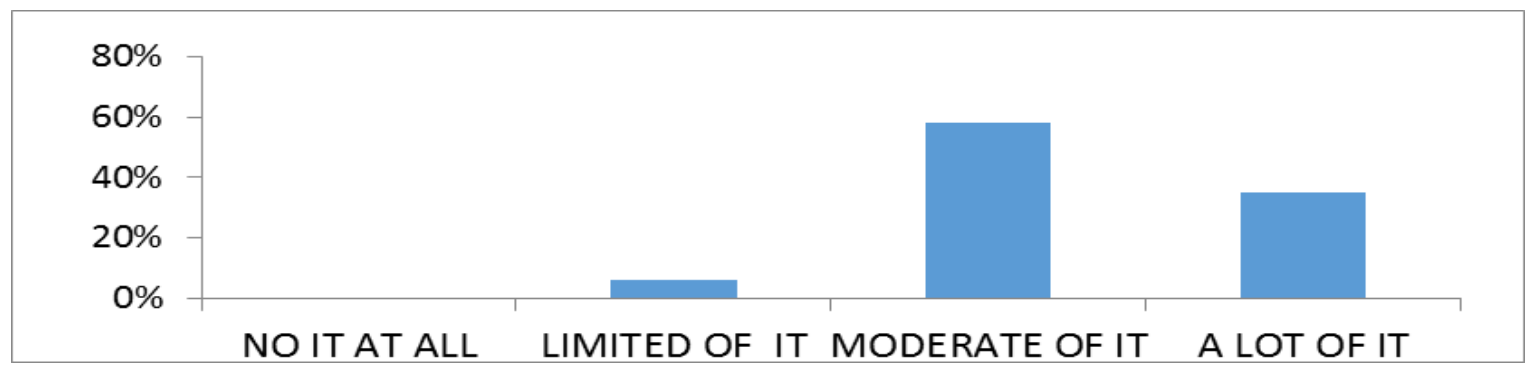

Figure 4. Learners' Expectation on Using IT in Education 


\subsection{Learners' Attitude on using ICT}

This following questionnaire demonstrated that most of learners (45\%) described themselves that they love new technologies and usually become the first one to try them. Moreover, $37 \%$ of learners like new technologies and usually use them before their friends do. It announced that the learners had a high adoption of IT. Please look at figure 5.

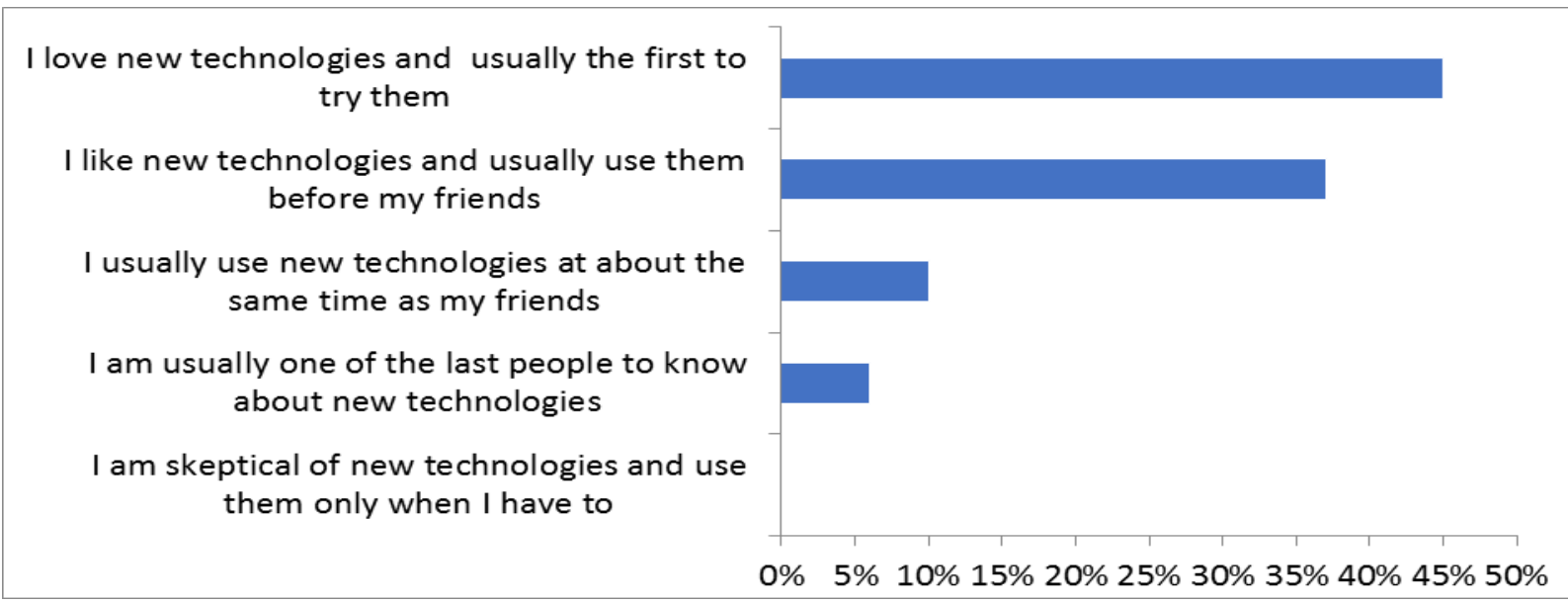

Figure 5. Learners' Attitude on using technology

\section{Discussion}

\subsection{Awareness level of millennial learners}

In the first section, this study explored the learners' awareness level on technology. The trend toward millennial using smartphone and laptop or computers instead of desktop computers replicates their preference toward a more movable learning environment. Majority of the learners (68\%) have laptops/computer, and all of them (100\%) own smartphones which are fully equipped with latest features and can be accessed exclusively both in the university and home. Similarly, this study also showed the excessive online activities by learners.

Millennial also used email to send and receive electronic letters that can be delivered within seconds around the world. They also use the internet that allows learners to access learning materials, to watch videos, and even to socialize. As Price (2011) asserted that millennials have grown up being able to Google anything they want to know, therefore they do not typically value information for information's sake. As a result, the professor's role is shifting from disseminating information to helping learners apply the information. One of the huge challenges for teachers is to attach course content to this culture and create learning outcomes and activities relevant. As evidence, this study examined the learners' involvement in internet activities.

\subsection{Millennial learners' attitudes and preferences in educational environment}

As noted previously, this study also aimed to illustrated the millennial learners' attitudes and preferences in educational environment. The most essential point of understanding the characteristics of the millennial learners is more complex. That point is simply this; the millennial learners are not entirely like their predecessor. There are some significant shifts from the millennial culture that we have been 
working with, and in some cases battling with, for the last two decades. The strategies that we have brought into the classrooms and campus life to engage millennial learners will need to be re-evaluated in light of the new generational personality that has moved on campus. Many of these shifts appear to be very positive, such as confidence, conventionality and team-orientation. Teachers must be prepared to adjust.

As digital natives, millennials clearly adapt faster to computer and internet services because they have always had them. While they still clearly need and expect professional teachers in a face-to-face atmosphere, they expect the speed, convenience, flexibility and power provided by digitally services and resources. Millennials are practical, if they are offered an online service, they expect it to work. Millennials expect all their academic services to be integrated digitally online so that they can pick and choose how and when they want to learn.

This study found majority of learners (58\%) choose search engine to find information rather than asking friends $(25 \%)$ or teachers $(17 \%)$. Millennials have an aptitude for technology because it is a natural language for them. They grew up with technology, used laptops, iPods, internet, cell phones, iPads, tablets, digital music players, video cameras, video game technologies and other forms of technology from an early age. As a result, they prefer video, audio and interactive media to learn. At the same time, most of the millennial learners (58\%) expected using IT in education moderately, even $35 \%$ of them expected a lot of IT in education. This circumstance showed the millennial learners do not rely teachers or peers to answer any questions they might have, but instead depending on the internet, since the internet served whatever their desired to know. As might be expected that Google is not a great, new innovations but simply part of their daily life needs. This characteristic had the biggest impact on the millennial learners and distinguishes them the most from other generations.

Equally important, the learners also shown their attitudes towards the technology. Millennials had and still have a mobile world where they can access information at any given time. Majority of the learners (45\%) loved technology and become the first to try them, likewise apart of them used it about the same time as their friends did. This use of technology has made millennials expect instant enjoyment. For instance, they can watch movie streaming via such application in their own smartphone. They do not need to go to the cinema. They also rely on technology, the more portable the better, and feel more comfortable communicating through technology than in person.

\section{Conclusion}

It is convincingly clear that the millennial learners of English Education program of UM Parepare are already exposed to various types of IT application. Some indications can be extracted from this study. Firstly, the learners were reasonably comfortable in utilizing various types of IT tools and expect the application to be embedded in the current application of learning. Secondly, the learners preferred to try to web for obtaining information, so the use of internet to access learning materials are highly needed. Thirdly, learners were mostly rated to expect high adoption to use most ICT tools and devices in education. However, since this study did not conduct interview, the result of this questionnaire do not dig into more deeply 
the reason why the millennial learners choose and expect much technology in education. Undoubtedly, this study suggested that the learning institution may have overlooked the importance of exploring the millennial learners' need and attributes and adjust their needs into the education environment

\section{References}

Aucoin, Robert Charles. (2014). A Study of Learners' Perceptions of the Use of Web 2.0 Applications in Higher Education. Retrieved on September 2015 from www.avantlearning.com

BadanStandar Nasional Pendidikan (BSNP). (2010). Paradigm PendidikanNasional Abad XXI. Retrieved on October 2016 from www.bsnp-indonesia.org/id/wpcontent/uploads/ 2012/04/Laporan-BSNP-2010.pdf

Beard, Schwieger, and Surendran (2007). Bridging the Academic /Industrial Chasm for the Millennial Generation. Information Systems Education Journal, 5 (33).Retrieved on September 2015 from http://isedj.org/5/33/. ISSN: 1545-679X.

Gardner S, and EngS .(2005). What learners want: millennial generation and the changing function of the academic library. Libraries and the Academy.Vol 5. Retrieved on January 2016 from https://muse.jhu.edu/article/185018/summary

Howe, N. \& Strauss, W. (1991). Generations: The History of America's Future, 1584 to 2069. William Morrow Paperbacks: New York City,

Khalid, Irfan. (2010). Role of Web 2.0 technologies for Knowledge Building in Higher Education. Master Degree Project. Sweden : Linnaeus University. Retrieved on September December 2015 from https://www.diva-portal.org.

McCrindleM. .(2003). Understanding Generation Y. Principal Matters.Vol. 55. Retrieved on December 2015 from : https : // search.informit.com.au /fullText;dn= 200305936;res=IELAPA

Nussbaum-Beach, S. and Hall, L.R. (2012). The connected educator: Learning and leading in a digital age. Bloomington, IN: Solution Tree. Retrieved on December 2015 from http://www.bookfi.net.

Oblinger, D. G., \&Oblinger, J. L. (2005). Educating the Net Generation: EDUCAUSE. Retrieved on January 2017 from https://www.educause. edu/...and.../educating -net-generation

Prensky, M. (2001).Digital natives, digital immigrants. On the Horizon, 9(5). Retrieved on January 2016 from http: // www. emeraldinsight.com /doi /pdf /10.1108 /10748120110424816

Regina ,Luttrell , and Karen McGrath. (2015). The Millennial Mindset : Unraveling Fact from Fiction. London : Rowman\& Littlefield Publishing Co. Retrieved on December 2015 from http://www.bookfi.net.

Starlink. (2004). Educating the NetGen: Strategies that work. Participant Packet. $\begin{array}{llll}\text { Retrieved on January } 2016 & \text { from }\end{array}$ http://www.starlinktraining.org/packets2004/packet129.pdf 
Sudrajat, Akhmad. (2012). Generasi Z danImplikasinyaTerhadapPendidikan. Blog Pendidikan. Retrieved on March 2016 from http://www.akhmadsudrajat.wordpress. Com

Sweeney, Richard (2006). Millennial Behaviors \& Demographics. Retrieved on March 2016 from http://unbtls.ca/teachingtips/pdfs/sew/Millennial-Behaviors.pdf

Tapscott, D. (1999). Educating the Net Generation. Educational Leadership, 56(5). Retrieved on January 2016 from https://eric.ed.gov/?id=EJ581511 